Jurnal DinamikA

Volume 1 No. 2 (2020)

E-ISSN: $2723-1410$

Website: https://jurnal.iainsalatiga.ac.id/index.php/dinamika/index

\title{
Social Classes Reflected By The Main Characters In Kevin Kwan's “Crazy Rich Asians” Novel
}

\author{
Difa Reza Pahlevi ${ }^{1}$, Eka Margianti Sagimin ${ }^{2}$ \\ ${ }^{1,2}$ English Department, Universitas Pamulang, Tangerang Selatan, Banten \\ Email: pahlevidiva@gmail.com ${ }^{1}$, ekamargy@yahoo.com ${ }^{2}$
}

\begin{abstract}
The aim of this study is to analyze the disparity of social class and the causes and effects of social class among two main characters in Kevin Kwan's "Crazy Rich Asians” novel (2013). To analyze the issue, Weber's theory of social class (1998) were used. The research methodology used in this study was a qualitative method. By using this method, it means a qualitative approach is used to describe the social phenomenon, life experiences and situations to give the meanings and also to explore the behavior, perspectives, experiences, and feeling of people in the form of an essay. Based on the analysis, some aspects that relate to the disparity and causes and effects of social class. Those are the types of social class disparity reflected by these two characters, the cause of social class between the two main characters and the effect that caused by its disparity of social class. The result of this study showed that these disparities can be lifestyle, ways of thinking and in choosing a partner. Also, social class can be caused by heredity and family background, the effects are someone who has a social class that is considered low, will be ostracized, or even terrorized.
\end{abstract}

Keyword : Qualitative Method, Social Class, Weber Theory.

\begin{abstract}
Abstrak
Penelitian ini bertujuan untuk menganalisis perbedaan kelas sosial, dan sebab akibat adanya kelas sosial pada novel karangan Kevin Kwan berjudul "Crazy Rich Asians" (2013). Untuk menganalisa masalah digunakan teori kelas sosial oleh Weber (1998). Metode penelitian ini menggunakan metode kualitatif. Dengan menggunakan metode ini, artinya metode kualitatif digunakan untuk menggambarkan fenomena social, pengalaman hidup dan situasi untuk memberi pemahaman dan untuk menelaah perilaku, perspektif, pengalaman dan perasaan seseorang dalam bentuk naratif. Dari hasil analisis ada beberapa aspek yang berhubungan dengan perbedaan kelas sosial dan sebab akibat adanya kelas sosial. Diantaranya adalah jenis perbedaan kelas sosial yang tercermin oleh dua karakter utama, penyebab adanya kelas sosial diantara dua karakter utama dan efek yang disebabkan oleh perbedaan kelas sosial keduanya. Hasil dari penelitian ini menunjukan bahwa perbedaan ini bisa berupa gaya hidup, cara berpikir dan dalam memilih pasangan. Kelas sosial juga dapat disebabkan oleh faktor keturunan dan latar belakang keluarga, hasilnya adalah seseorang yang memiliki kelas sosial yang dianggap rendah, akan dikucilkan, bahkan diteror.
\end{abstract}

Kata kunci : Kelas Sosial, Metode Kualitatif, Teori Weber. 


\section{Introduction}

Society consists of diverse group of people, with different characteristics. The differences can usually be religion, gender, race, age or even their income and education. These differences are even made a hindrance to someone when they want to do an activity in society. According to MacIver and Page (1950) "Society is a system of usages and procedures, of authority and mutual aid, of many groupings and divisions of human behavior and of liberties. This everchanging complex system we call society. It is the web of social relationships". In carrying out social life, some of these differences will be found and the main difference in society is social class.

Giddens (2006) stated that a group of people within a society who possess the same socioeconomic status is called social class. Social class is made up of people of similar social status who regard one another as social equals. Each class has a set of values, attitudes, beliefs and behavioral norms that differ from those of the other classes. Social class categories are usually arranged in a hierarchy, which ranges from low to high social status. Thus, members of certain social classes would feel the members of other social classes have higher or lower social status than them. The hierarchical aspect of social class is an important thing for the economic agents. For instance, consumers of the certain social classes will buy a product because this product is liked by members of their own social class or higher social class than them. Systematic approaches to measuring social class divided into the following broad categories: subjective measures, measures of reputation and objective measures of social class. According to Giddens (2006), "a class is a large-scale grouping of people who share common economic resources, which strongly influence the type of lifestyle they are able to lead" it means the social class of the people will affect to the way they lived and their needs as a human and the factors of social class commonly affect their beliefs, attitudes, activities, and behavior, it tends to distinguish members of each class from members of other social classes. Weber (1998) stated that social class refers to any group of people who have the same typical chance for a supply of goods, external living conditions, and personal life experiences.

People can be indicated in which the social class they belong by some indicators. But the most thing that can indicate the people's class is by the money itself. According to Horton \& 
Jurnal DinamikA

Volume 1 No. 2 (2020)

E-ISSN: 2723-1410

Website: https://jurnal.iainsalatiga.ac.id/index.php/dinamika/index

Hunt (1980) The determinants of social class can be the specific aspect to support the depiction of the social class, the first is income which is the main measure to indicate the class that someone belongs. People that have high income can be indicated as the upper class because they can do anything with their money. The second is the occupation which is an exceedingly important aspect of social class because many other facts that are connected with the occupation. Generally, from knowing someone's occupation, the other people can know their educational background, standard of living, and their daily routines of her/his family life. The third is education, social class and education interact at least two ways. Higher education requires money and motivation. Then, the amount and kind of education affects the class rank secured. It does not only bring occupational skills, but it also brings changes in taste, interest, goals and speech in one's total way of life. Although a wealthy family background is a necessity for secure upper-class status, education may substitute for family background at the intermediate class levels. The fourth is self-identification and class consciousness, selfidentification with social class has some effect upon behavior, whether one is a member of that class or not. The fifth and the last determinants is status symbol, since the rich and wellborn look like other people, they need the meaning of ensuring that their position is recognized. In the past, it has been found through the status symbol, which can be any desirable trait or object that supplies sharply limited such as private swimming pool and diamonds (Horton \& Hunt, 1980).

The example of where social classes are visibly seen is the social class situation in the Philippines. According to Manlove (2002) in his journal "Inequality in Urban Philippines" There are several types of social inequality in the Philippines. There is inequality based on ethnicity, gender, land ownership, linguistic ability, and religious affiliation. The other types of social inequality can be seen either as extensions of the class system to particular settings (e.g., the church or the classroom) or as the class system in which one dimension (e.g., land ownership or ethnic identity) is emphasized. Class stratification is the framework in which all of the other inequality happens. 
Manlove (2002) stated that there are four social categories that seen within the community: (1) Datu stratum (principals or maginoo), The datu stratum controlled access to land and in that regard the strata could properly be identified as estates. members of this elite could hope to become a datu by demonstrating prowess in war and/or exceptional leadership. (2) Upper class or Maharlika is the social class has high income, wealthy and economic influence; (3) Middle class or Timawa is the center category are the little businessmen, teachers, merchants, traders with modest income; and (4) Lower class or Alipin is the lowest class of the hierarchy, a socioeconomic class has earning low incomes with a touch or no savings; some are at leisure.

Based on the background above, the topic of social class in a novel by Kevin Kwan entitled "Crazy Rich Asians” which released in 2013 is chosen. In "Crazy Rich Asians” social class issues are shown very clearly, a struggle between an upper-class who fell in love with a middle-class is a description of the conditions when social class differences can prevent someone from doing something. This story is about Nick Young, an upper-class people who come from an extremely wealthy family in Singapore and Rachel Chu, a middle-class Californian girl who became a professor in New York University.

\section{Social Class}

The social classes according to Weber (1998) refers to any group of people who have the same typical chance for a supply of goods, external living conditions, and personal life experiences. This chance is determined by the power to dispose of goods or skills for the sake of income in a given economic order, the basic condition of the social class made the unequal distribution of economic power and hence the unequal distribution of opportunity. That is defined by things such as occupation, their incomes and many more. Based on classical social class studies and theories, many observations have empirically examined the determinants and effects of social class and inequality. Multidisciplinary understanding in this topic is not only diverse and insightful, but additionally fragmented and has many facets.

A social class system can be defined as a system for generating social wealth where productive resources and the productive results are not shared equally among various groups in society "Social class or social group refers to the stratifications between human beings or groups 
Jurnal DinamikA

Volume 1 No. 2 (2020)

E-ISSN: 2723-1410

Website: https://jurnal.iainsalatiga.ac.id/index.php/dinamika/index

in society. The divisions have several classes or groups in society that are defined by a particular position in the production process" (Suseno, 2001). But it is central to Marx's theory of class, that there is a primary cleavage between owners of the means of production and the direct producers, and that this cleavage embodies a fundamental conflict of interest between one group and another. it can be concluded that social class is the differentiation of population or society into multilevel classes or also called as a hierarchy, which determines the class distinction in this society based on economic, educational, occupational and interrelated status (decision). Status of the family that is laid down, when the position of head the family rises, so the status of family members who take part also While the manifestations are layers or classes of high, medium, or low classes. According to Berger (1980) "social class is a type of stratification in which one's general position in society is basically determined by economic criteria". Berger's statement can be concluded that the higher a person's economy it means the higher their position in society.

Earnings and income, including wealth and money owned are the main factors that determine a person's social class. A person's wealth will determine their lifestyle. People who have a lot of money can buy a variety of luxury tertiary goods such as cars, luxury watches, jewelry, and much more. That is why wealth is an important determinant in social class. For them, the economy is good and has above-average financial capacity, including the high-class category, as well as for those whose economies are just well-off they belong to the middle-class category, middle-class life tends to be stable and orderly. The last is the lower class, as the lowest class in social stratification, the people belonging to this class are the ones who feel the sharpest social gap between the lower classes and other classes in society. The lower classes have difficulty accessing various public services, resources and employment. Lower class people are spread in various areas, ranging from urban, rural, to people who live far from the center of development.

Social class in a majority of society in the world is very important because the formation of social class is based on wealth, power and prestige, that three based components are separating people into different lifestyles, giving them different life opportunities, and giving them different ways to do their role in society. 
People in the lower classes might have the assumption that God created human beings all the same and there are no differences between them. However, this assumption is not necessarily recognized by those in the upper class, because they maybe think that people who come from the upper social class have more rights than those from the lower social class

\section{Disparity Of Social Class}

In every society there are disparities, it is commonly called social stratification in which a society tends to divide into separate classes whose members have different access to resources and power which are depicted by high and low status in society. For instance, people's income varies depending on the ability that they have. For those who have the highest income around their society, they are categorized as an upper class.

According to Weber's theory in Brennan (1997) The disparity of social classes in society are formed by a three-components theory of stratification in which social disparity is determined by class, status and power, which means: class is a person's economic position in society it can be based on their birth or their individual achievement.

a. Status is one's social prestige or honor, which may or may not be influenced by class.

b. Power means a person's ability to get one's way despite the resistance of others.

Also he is stated that there are four main classes:

a. The upper class which is the social group that has the highest status in society

b. The white-collar workers that means a person who performs professional, managerial or administrative work.

c. The petite bourgeoisie that belonging to the lower middle social class

d. The manual working class or laboring class comprises those engaged in waged or salaried labor.

The formation of a hierarchy of pyramid of group differentiated by their possession of greater and lesser amounts of these advantages constitutes the class structure of society (Sills, 
Jurnal DinamikA

Volume 1 No. 2 (2020)

E-ISSN: 2723-1410

Website: https://jurnal.iainsalatiga.ac.id/index.php/dinamika/index

1972). By using Sills statements, advantages in society are made of people, and society's resources are distributed unevenly throughout the people in society.

The people who have more resources represent the topper position of the social structure of stratification called upper class, the ownership of large amounts of resources and the income originated from it giving many advantages upon the members of the upper class. They are able to develop different lifestyles based on their broad livelihoods to have a great influence on economic policy and political decisions, and to give their next generation in their family a superior education and economic opportunities that help preserve family wealth. Other groups of people, with progressively fewer and fewer resources, represent the lower position in the society and the basic stratification under upper class is a middle class who have enough resources of their income, usually, they are consists of a group of people who are well off, who are able to meet basic needs so they can have an adequate life. The last is the lower class, those who have very limited resources for their income in society is a lower class, those who may have permanent jobs but still have financial difficulties to cover their needs.

Thus, members of certain social classes accept members of other social classes who have a higher or lower status than those who are from other social classes, social patterns and lifestyles have given their awareness of the social class they have, because they do not want to be in a lower social class, but they understand the social class they have been classified by some aspects, therefore this social class consciousness will bring different patterns of behavior between one social class and another. The social patterns and lifestyles of each social class make the social class they have as a sub-culture in every social structure.

\section{Causes And Effects Of Social Class}

Inequality of social class in a society according to Weber (1998) has several causes and effects, in every country, the causes and effects are varied and the most common causes of this social class is heredity Weber stated that "class situation is designated as every typical component of life fate of men that is an honor, it is normally expressed by the fact that a specific style of life can be expected from all those who wish to belong to the circle. Linked with this expectation are 
restrictions on social intercourse (that is, intercourse which is not subservient to economic purposes). These restrictions may confine normal marriages within the status circle". In this case, the fate of someone who was born in a certain social class can limit them to do something, and one of the things is a marriage that is often determined by social classes.

The ability and opportunity a person has to achieve better status in society are known as a person's life chances. There are various factors that can determine a person's life chances including genetic inheritance, social class of parents, education, childhood poverty, family, attitudes and discrimination, plus many more (Aldridge, 2004). When a person is born in an upper-class family, of course, they will more easily get a variety of facilities, for example a role of social classes in the fields of education and occupation. In these fields for instance, a person's social class has a significant impact on their educational opportunities. Not only can upper-class parents send their children to exclusive schools that are considered better than any public school, but in many cases, government-supported schools for children from the upper classes are having much better quality than the state provides for children from the lower classes.

Stiglitz (2012) stated that social classes that make inequality of opportunity can entail large social costs (for some people in a certain social class). Entrenched inequality of outcomes can significantly undermine individuals' educational and occupational choices. With this statement, the effect of social class can be felt by everyone from each social classes. The inequality of their social class sometimes can determine how the quality of education and occupation that they will get, it is very common when someone from the lower social class has limitations of opportunity in accessing education or occupation.

Coser (1956) says that social conflict may be defined as a struggle over values or claim to status, power and scarce resource in which the aims of conflicting parties are not only to gain the desires values but also to neutralize, injure, or eliminate their rivals. As a result of the existence of social class, sometimes a person or individual in society has one or more conflict that caused by their social class. If the social class they have makes them difficult to do social activities, there will be a conflict or an opposition. That is the effect of social class. So the consequences arising from a person's social class is the emergence of social conflict, there is always a conflict because 
Jurnal DinamikA

Volume 1 No. 2 (2020)

E-ISSN: $2723-1410$

Website: https://jurnal.iainsalatiga.ac.id/index.php/dinamika/index

conflict is common in social interactions and it is a way of understanding society.

\section{Research Method}

This study is conducted by collecting and analyzing the data. The researcher is searching for the answers to what social class issues that showed by the author's perspective. This study is using a qualitative research as stated by Denzin and Lincoln (1994):

"Qualitative researchers stress the socially constructed nature of reality, the intimate relationship between the researcher and what is studied, and the situational constraints that shape inquiry. They seek answers to questions that stress how social experience is created and given meaning [...] Qualitative forms of inquiry are considered by many social and behavioral scientists to be as much a perspective on how to approach investigating a research problem as it is a method"

By using this method, it means a qualitative approach is used to describe the social phenomenon, life experiences and situations to give the meanings and also to explore the behavior, perspectives, experiences, and feeling of people and emphasize the understanding of the elements. The writer can easily collects all information from the data, yet the data itself is from a "Crazy Rich Asians" novel written by Kevin Kwan. The writer tends to reveal all information about the social class from other related studies, and also the writer finds other sources about the racial discrimination approach from the websites.

\section{Finding And Discussion}

Social classes are shown very clearly by the characters in this novel, especially the main characters Rachel Chu and Nick Young. Rachel Chu, a 28-year-old Californian girl with a Chinese descent who works as an Economics professor at New York University, has been happily dating with Nick Young, a 32-year-old Singaporean History professor that is also at New York University. Nick and Rachel have different family backgrounds, Nick came from a very wealthy family in Singapore, while Rachel is only the daughter of a single parent who migrated from Shenzhen, China and tried to start a new life in America. At the first Nick did not tell her family background to Rachel, and Rachel also did not seem to have thought that Nick had a rich family, until one day Nick asks Rachel to go to Singapore to attend the wedding of his best friend Colin 
Khoo, as well as taking Rachel to meet his family in Singapore.

Nick does not know how to explain about his wealthy and powerful family in Singapore and also his opulent life to Rachel, since it is so far if compared to their common lives as professors in New York. He asks for an advice to his cousin and a person that he trusts so much, Astrid Leong, and she warns him several times to prepare Rachel for the culture shock in Singapore, Astrid also afraid about a social class difference that would make Rachel think about it. "You know what will happen the minute you land at Changi Airport with this girl on your arm, don't you? You know how brutal it was for Michael when we first started going publicity. That was five years ago, and he's still getting used to it. Do you really think Rachel is ready for all that? Are you ready for it?" (Kwan, 39)

The quotation above shows that Astrid knew what will happen to Nick and Rachel when they landed for the first time in Changi Airport, they would be in the public and media spotlight in all over Singapore. Astrid is worried that Rachel would be shocked by such a thing, and if Rachel knew that Nick's family is very influential in Singapore it is not impossible their relationship will change into something that they never imagine, Astrid says so because she felt that thing when she and her husband Michael showing their relationship into public for the first time, Michael who is a former military officer and became a businessman is not being used to a "rich person's" life but after he married with Astrid who is a daughter of Harry Leong and Felicity Young he must be accustomed to living like that. By birth, Astrid is a member of two prominent and influential families in Southeast Asia, the Leongs and the Youngs. With her experience of dealing with things like this, Astrid hopes Nick can understand about this condition and wants Nick to tell gradually to Rachel about their family and not suddenly bring her to his "real life" then force Rachel to get used to it.

But unfortunately, Nick prefer not to heard that advice from Astrid, he defiantly thinks that he should be able to bring his girlfriend to meet his family together with him and without making a big trouble.

Before Nick and Rachel leave New York to go to Singapore, a rumor has spread to the Singaporean upper-class people. It was begun when Nick and Rachel had a conversation in a tea shop named Tea \& Sympathy, they were sitting at their usual window table and the girl at a 
Jurnal DinamikA

Volume 1 No. 2 (2020)

E-ISSN: $2723-1410$

Website: https://jurnal.iainsalatiga.ac.id/index.php/dinamika/index

neighboring table realize that he is Nicholas Young, a cousin of the Leongs, a family that wellknown amongst the upper-class people in Singapore. They were overheard that Nick invited an unknown girl who sat next to him named Rachel to the Singaporean wedding of the year between a billionaire Colin Khoo and supermodel Araminta Lee. "Is that of the Leongs brothers?" (Kwan, 17) asked by the mother of the girl, thinking that she is recognizing him, showing that Nick's family is one of the most famous families in Singapore. "...He's Nicholas Young, a cousin of the Leongs...he's just back from Oxford. Double-majored in history and law" (Kwan, 17). The quotation above is stated by Charlotte, the girl who sat at the neighboring table are Charlotte and Celine Lim, long time ago Celine and Charlotte has spotted him at the Pulau Club which is Singapore's most prestigious country club, again it is depicted that Nick is coming from an upper-class family. Then while they are continually talking about Nick, another girl of its group Hannah tried to snap a picture of Nick, then its picture and rumor has spread rapidly through the networks of the Asian jet set, and within a few hours, almost everyone in their circle knew about this big news.

A family background of Rachel that is not accepted by Nick's family makes it clearly shows that the cause of social class in someone's life can be because it is a thing that is passed down through generations without being able to be rejected by the next generation of its family. As a result of the existence of social class, sometimes a person or individual in society has one or more conflict that caused by their social class. If the social class they have makes them difficult to do social activities, there will be a conflict or an opposition. That is the effect of social class. So the consequences arising from a person's social class is the emergence of social conflict, there is always a conflict because conflict is common in social interactions and it is a way of understanding society.

The conflict caused by social class also happened to Rachel when Nick's family, especially her mother, really wanted Nick to end his relationship with Rachel in various ways, trying to intimidate Rachel so that she felt she is not deserved to be in Nick's family. Eleanor and her friends perpetuate the rumors about Rachel, she heard those rumors that led into something she did not like. As they try to turn the island against her while making several attempts to break 
Rachel and Nick up.

"To Eleanor, every single person occupied a specific space in the elaborately constructed social universe in her mind. Like most of the women in her crowd, Eleanor could meet another Asian anywhere in the world say, over dim sum at Royal China in London or shopping in the lingerie department of David Jones in Sydney and within thirty seconds of learning their name and where they lived, she would implement her social algorithm and calculate precisely where they stood in her constellation based on who their family was, who else they were related to, what their approximate net worth might be, how the fortune was derived, and what family scandals might have occurred within the past fifty years" (Kwan, 57-58)

As a member of an upper-class family in Singapore, Eleanor always had access to investigate information about someone or something she wanted to know and this time she was investigating Rachel by relying on several people, Eleanor starts to share this and asks for advice from her friends when they meet at Bible study on her friend's house, Carol Tai. They are gathered for a Bible study among upper-class women, some of them gave bad opinions about Rachel, especially related to her background as an ABC (American-born Chinese) "So disgraceful! Sharing a hotel room when they aren't even married you know, some people might think they eloped and are coming here for their honeymoon!... How dare this girl thinks she can just waltz right into Singapore on Nicky's arm and attend the social event of the year without your approval? She has no clue how things work here" (Kwan, 105). One of Eleanor's friends, Nadine Shaw gave an opinion that made Eleanor even angrier, in Nadine's opinion, Rachel had a bad influence for Nick, making him forget about Eastern traditions and way of life and make him follow the Westernized lifestyle. Among Asians who are still strong in traditions, what Nick and Rachel did by sharing a hotel room when they are not married is considered taboo and not accordance with the norms of Asian society, something that happens to Nick's family who still holds strong their traditions and wants that tradition to continue in their family's generation, of course with people who fit the criteria of Nick's family, especially his mother Eleanor who wants Nick to have a Singaporean upper-class wife to continue their wealth.

Among the upper-class Singaporean people, they have a bad stigma about ABC (Americanborn Chinese), they think that those who are Chinese and staying in America from generation to 
Jurnal DinamikA

Volume 1 No. 2 (2020)

E-ISSN: $2723-1410$

Website: https://jurnal.iainsalatiga.ac.id/index.php/dinamika/index

generation is not even better than them who lives in Singapore, because, in their opinion, the Chinese who go to America then settle down and have children in America is people who fail to survive and are too stupid to survive in Mainland China “...Everyone knows these ABC's and descended from all the peasants that were too stupid to survive in China!" (Kwan, 106). Nadine continues to give opinions about Rachel and again, she gave a lot of negative words to Eleanor about Rachel and her family background, making Eleanor increasingly convinced that Rachel is not the right woman for Nick.

\section{Conclusion}

To analyze the disparity of social class in the characters of "Crazy Rich Asians" novel. This study concluded that the disparity of social class shown by the main characters in this novel, it shows that social class differences between Nick and Rachel's as the main characters can be seen from their family, Nick and Rachel have different family backgrounds, Nick from upper social class has a luxurious life while Rachel is from a middle class family. This causes disparity that occur such as: differences in social status between them, differences in perspective, way of thinking and way of life.

Furthermore, social class in "Crazy Rich Asians" novel has some causes and effects, their family background causes the differences of their social classes. All Nick's extended family has super-rich tastes and preferences that Rachel can't reach. Appearance is everything, money is everything, this is something experienced by Rachel, the differences between her and Nick create a conflict between Rachel and Nick's family, according to Nick's family, Rachel is not a woman who deserves to be Nick's wife due to several reasons and criteria applied by Nick's family requires her family to choose a partner from the same social class as them, that is, the upper social class

The super-rich are shown in this novel with a full of ego, sometimes overriding reason. Men are doing bachelor parties, women shopping and spas. This creates an unavoidable conflict because Nick's family wants a wealthy woman for Nick to continue his family wealth. 


\section{References}

Aldrigde, S. (2004). Life Chances $\mathcal{E}$ Social Mobility. London; Cabinet Office.

Berger, P. (1980). Invitation of Sociology: A Humanistic Perspective. New York; Doubleday Company

Brennan, C. (1997). Max Weber on Power and Social Stratification: An Interpretation and Critique. Aldershot; Avebury.

Chaudhary, A. (2019). Retrieved December 28, 2019 from Bloomberg News: https://www.bloomberg.com/quicktake/india-s-caste-system.

Coser L. (1956). Function of Social Conflict. New York; Free Press.

Denzin, N. \& Lincoln, Y. (1994). Handbook of Qualitative Research. California; SAGE Publishing.

Fatmawati, Y. (2014). Eliza's Struggle to Achieve The Higher Social Class Status in Pygmalion George Bernard Shaw. Surabaya. Faculty of Letters and Humanities.

Giddens, A. D. (2006). Sociology $5^{\text {th }}$ Edition. Cambridge; Polity Press.

Horton, P. B. \& Hunt, C. L. (1968). Sociology $2^{\text {nd }}$ Edition. New York; McGraw-Hill.

Jones, E. (1968). Outline of Literature: Short Story, Story: Novel and Poem. New York; The Macmillan Company.

MacIver, R. M. \& Page, C. H. (1950). Society: An Introductory Analysis. New York; The Macmillan Company.

Manlove, R. F. (2002). Social Inequality in Urban Philippines. Retrieved January 11, 2020.

Morina. (2013). An Analysis of Social Class and Social Struggle in "The Hunger Games" Movie Using Marxism Theory. Jakarta. English Departement Faculty of Letters.

Perrine, L. (1974). Literature: Structure, Sound and Sense. California; Harcourt Brace Jovanovich.

Pruitt, D. G. (1998). Handbook of Social Psychology (4 ${ }^{\text {th }}$ ed., Vol.2, pp. 470-503). New York; McGraw-Hill. 
Jurnal DinamikA

Volume 1 No. 2 (2020)

E-ISSN: $2723-1410$

Website: https://jurnal.iainsalatiga.ac.id/index.php/dinamika/index

Rizal, K. (2017). The Struggle of Lower Class As Seen in "Mad Max: Fury Road". Yogyakarta. Faculty of Adab and Cultural Science.

Roberts, E. V. (1995). Literature: An Introduction to Reading and Writing. New Jersey; Prentice Hall.

Sill, D. (1972). International Encyclopedia of the Social Sciences. London; The Macmillan Company.

Stiglitz, J. (2012). The Price of Inequality: How Today's Divided Society Endangers our Future. New York; W. W. Norton.

Sumardjo. (1998). Apresiasi Kesusastraan. Jakarta; PT. Gramedia.

Suseno, F. M. (2001). Pemikiran Karl Marx, Dari Sosialisme Utopis ke Perselisihan Revisisonisme. Jakarta; PT. Gramedia.

Weber, Max. (1998). From Max Weber: Essays in Sociology. Oxfordshire; Routledge Publisher.

Wellek, R. \& Warren, A. (1982). The Attack on Literature and Other Essays. North Carolina. The University of North Carolina Pres. 